\title{
Similar patterns of rDNA evolution in synthetic and recently formed natural populations of Tragopogon (Asteraceae) allotetraploids
}

\author{
Hana Malinska', Jennifer A Tate ${ }^{2}$, Roman Matyasek ${ }^{1}$, Andrew R Leitch ${ }^{3}$, Douglas E Soltis ${ }^{4}$, Pamela S Soltis ${ }^{5}$,
} Ales Kovarik ${ }^{1 *}$

\begin{abstract}
Background: Tragopogon mirus and T. miscellus are allotetraploids $(2 n=24)$ that formed repeatedly during the past 80 years in eastern Washington and adjacent Idaho (USA) following the introduction of the diploids T. dubius, T. porrifolius, and T. pratensis $(2 n=12)$ from Europe. In most natural populations of T. mirus and T. miscellus, there are far fewer $35 \mathrm{~S}$ rRNA genes (rDNA) of $T$. dubius than there are of the other diploid parent ( $T$. porrifolius or $T$. pratensis). We studied the inheritance of parental rDNA loci in allotetraploids resynthesized from diploid accessions. We investigate the dynamics and directionality of these rDNA losses, as well as the contribution of gene copy number variation in the parental diploids to rDNA variation in the derived tetraploids.
\end{abstract}

Results: Using Southern blot hybridization and fluorescent in situ hybridization (FISH), we analyzed copy numbers and distribution of these highly reiterated genes in seven lines of synthetic T. mirus (110 individuals) and four lines of synthetic T. miscellus (71 individuals). Variation among diploid parents accounted for most of the observed gene imbalances detected in $F_{1}$ hybrids but cannot explain frequent deviations from repeat additivity seen in the allotetraploid lines. Polyploid lineages involving the same diploid parents differed in rDNA genotype, indicating that conditions immediately following genome doubling are crucial for rDNA changes. About 19\% of the resynthesized allotetraploid individuals had equal rDNA contributions from the diploid parents, $74 \%$ were skewed towards either T. porrifolius or T. pratensis-type units, and only $7 \%$ had more rDNA copies of T. dubius-origin compared to the other two parents. Similar genotype frequencies were observed among natural populations. Despite directional reduction of units, the additivity of $35 \mathrm{~S}$ rDNA locus number is maintained in $82 \%$ of the synthetic lines and in all natural allotetraploids.

Conclusions: Uniparental reductions of homeologous rRNA gene copies occurred in both synthetic and natural populations of Tragopogon allopolyploids. The extent of these rDNA changes was generally higher in natural populations than in the synthetic lines. We hypothesize that locus-specific and chromosomal changes in early generations of allopolyploids may influence patterns of rDNA evolution in later generations.

\section{Background}

Chromosome counts suggest that between 30 and $100 \%$ of angiosperm species are polyploids [1], and Wood et al. [2] propose that $15 \%$ of angiosperm speciation events are associated with polyploidy whereas recent genomic studies of selected model and crop species

\footnotetext{
* Correspondence: kovarik@ibp.cz

${ }^{1}$ Institute of Biophysics, Academy of Sciences of the Czech Republic, v.v.i, Laboratory of Molecular Epigenetics, Kralovopolska 135, CZ-61265 Brno, Czech Republic

Full list of author information is available at the end of the article
}

have revealed that all plant genomes sequenced to date have signatures of one or more whole-genome duplications in their evolutionary history [3,4]. The success of newly formed angiosperm polyploids is partly attributable to their highly plastic genome structure as manifested by deviations from Mendelian inheritance of genetic loci and chromosome aberrations [5]. Indeed, there are numerous examples of intergenomic exchanges, chromosomal translocations, transposon proliferation, and sequence loss in both newly formed and ancient allopolyploid species (for review see [6,7]). 
In plants, nuclear ribosomal DNA (rDNA) units occur in tandem arrays at one or several loci (for review see $[8,9])$. Each large $35 \mathrm{~S}$ rDNA unit contains the $18 \mathrm{~S}$, $5.8 \mathrm{~S}$, and $26 \mathrm{~S}$ rRNA genes, the internal transcribed spacers (ITS), and the intergenic spacer (IGS). The $5 \mathrm{~S}$ genes encoding 120-nt transcripts are usually, but not always [10], located at different chromosomal loci than $35 \mathrm{~S}$ rDNA. The genes are highly conserved even between eukaryotes and prokaryotes, whereas divergence of ITS is sufficient to resolve species relationships within most genera [11]. The IGS, which contains the transcription start site and genetic and epigenetic features that influence the regulation of the downstream genes, diverges rapidly, and substantial differences in structure may occur even within a species [12-14]. The number of gene copies may vary from 500 up to tens of thousands in certain plant species [15]. Similar variation has been observed in locus number, with levels ranging from one to several loci per haploid set [16]. Within species, the copy and locus number is usually stable, although intraindividual and intergenerational variation in copy number has been reported in some plants [17]. As with other repeated sequences, rDNA can undergo concerted evolution involving sequence homogenization $[18,19]$. Such a process efficiently eliminates mutated copies maintaining long arrays of functional tandemly arranged genes.

The behavior of rDNA in allopolyploids has attracted considerable attention because it is used as a molecular and cytogenetic marker of allopolyploidy [20]. Indeed, the hybrid origin of many species has been successfully deciphered using ITS sequences. Nevertheless, repeat and locus loss, and intra- and interlocus recombination seem to be ongoing evolutionary processes, potentially preventing identification of hybrids. In fact, many welldefined allopolyploid species have either lost one or several loci [21-23], eliminated or contracted parental arrays [24-26], recombined [27] or replaced the units $[28,29]$. On the other hand, some polyploid species seem to maintain both parental copies in the genome long after allopolyploid formation [14,30-33]. These studies indicate that the process of rDNA evolution is complicated, and that no firm conclusion can be drawn on the tempo and direction of repeat homogenization. Nevertheless, there are examples of synthetic allopolyploid lines in which rDNAs have already undergone rearrangements at the chromosomal and unit levels $[13,34,35]$.

Recently formed allopolyploids represent unique natural systems in which to study the immediate consequences of allopolyploidy. Only a few polyploid plant species are known to have formed in the past 200 years: Cardamine schulzii [36], Spartina anglica [37], Senecio cambrensis and S. eboracensis [38], Tragopogon mirus and T. miscellus [39]. Cardamine allopolyploid populations seem to evolve recombined ITS types [40]. In Spartina anglica, the two individuals collected from different localities differed in the composition of rDNA units [41].

Allotetraploid Tragopogon mirus and T. miscellus formed in the Palouse region (eastern Washington, and western Idaho, USA) within the last 80 years $[39,42]$ and thus represent an excellent model for examining early events in allopolyploid evolution. Recent studies using different methodological approaches have shown frequent loss of homeologous sequences, including lowcopy protein-coding genes $[43,44]$ and high-copy rDNA [45]. In the latter, a population-level analysis revealed reduction of rDNA arrays derived from the $T$. dubius diploid parent in all but one natural population examined (T. mirus). While the average magnitude of gene loss was about $50 \%$, there were individuals that lost as many as $95 \%$ of all repeats. Cytogenetic studies confirmed that rearrangements were homologous and were not linked to chromosome loss [46].

The interpretation of genetic variation in natural polyploids is always complicated by the fact that genetic parents are unknown even in the case of recently formed species. That is, some allopolyploids may start out with far more rDNA copies of one parent than the other, simply because the diploid parents differ in copy number. On the other hand, genotypic variation may arise from genetic changes induced by stressful conditions experienced during allopolyploidy [5]. In this study we asked: (i) What is the contribution of parental diploids to copy number variation in newly formed allopolyploid $T$. mirus and T. miscellus? (ii) What are the dynamics of rDNA rearrangements, and do they occur suddenly or gradually? (iii) Is there a directionality and genetic predisposition for locus rearrangement? (iv) Are there parallels in the evolution of rDNA in natural and synthetic populations of the two allopolyploids? (v) What are the likely mechanisms of rDNA rearrangement? To address these questions we synthesized allotetraploid lines of T. mirus and T. miscellus [47] using several different populations of parental accessions. We determined homeolog gene ratios by Southern blot and slot blot hybridization. The locus numbers were assessed using FISH. Evidence was obtained for repeat loss in early generations of synthetic allopolyploid lines at frequencies and directionality similar to those observed in natural situations.

\section{Methods}

\section{Plant material}

Field-collected seeds of three diploid Tragopogon species were planted and selfed for one generation. Then 103 different crosses were made between individuals from three populations of $T$. dubius $(2613,2615,2616)$, two 
Table 1 Parental origin of synthetic allotetraploids and direction of crosses

\begin{tabular}{|c|c|c|c|c|c|c|c|c|c|c|c|}
\hline \multirow[b]{2}{*}{ Line } & \multicolumn{7}{|c|}{ T. mirus } & \multicolumn{4}{|c|}{ T. miscellus } \\
\hline & 70 & 73 & 98 & 116 & 121 & 134 & 135 & 67 & 79 & 111 & 129 \\
\hline $\begin{array}{l}\text { parents } \\
\$ \times 0^{\prime \prime}\end{array}$ & $\begin{array}{c}2611 \times \\
2613\end{array}$ & $\begin{array}{c}2611 \times \\
2613\end{array}$ & $\begin{array}{c}2611 \times \\
2613\end{array}$ & $\begin{array}{c}2607 \times \\
2615\end{array}$ & $\begin{array}{c}2615 \times \\
2607\end{array}$ & $\begin{array}{c}2607 \times \\
2613\end{array}$ & $\begin{array}{c}2613 \times \\
2607\end{array}$ & $\begin{array}{c}2609 \times \\
2616\end{array}$ & $\begin{array}{c}2609 \times \\
2616\end{array}$ & $\begin{array}{c}2608 \times \\
2613\end{array}$ & $\begin{array}{c}2613 \times \\
2608\end{array}$ \\
\hline${ }^{1} \mathrm{~N}$ & 9 & 48 & 7 & 28 & 8 & 14 & 16 & 15 & 22 & 39 & 3 \\
\hline${ }^{2} \mathrm{~S}_{0}$ & 2 & 3 & 1 & 1 & 0 & 1 & 1 & 2 & 1 & 4 & 1 \\
\hline${ }^{2} \mathrm{~S}_{1}$ & 7 & 34 & 6 & 27 & 8 & 13 & 15 & 13 & 21 & 35 & 2 \\
\hline${ }^{2} \mathrm{~S}_{2}$ & 0 & 11 & 0 & 0 & 0 & 0 & 0 & 0 & 0 & 0 & 0 \\
\hline
\end{tabular}

${ }^{1}$ total number of individuals analyzed by Southern blot hybridization.

${ }^{2}$ numbers in $S_{0}-S_{2}$ generations; the $S_{2}$ was the progeny of selfed $S_{1}$ parents $(73-14,73-1,73-2)$ that have been analyzed in this study by molecular and cytogenetic approaches.

populations of $T$. porrifolius $(2607,2611)$, and two populations of $T$. pratensis $(2608,2609)$ from different localities (Table 1, Table 2 and [47]). Seeds from successful crosses were treated with 0.1 or $0.25 \%(\mathrm{w} / \mathrm{v}$, water solution) colchicine during germination (overnight), washed, and placed in pots with soil. Approximately 6 months after germination, young plants were genotyped to determine their parentage using a marker (TDF 85) specific for all three diploid species [43,47]. The non-treated $F_{1}$ diploid hybrids were planted as controls. Detailed information about crosses is described in $[44,47]$.

\section{Molecular cytogenetic analysis}

Root tips cut from vigorously growing plants were pretreated with $2 \mathrm{mM}$ 8-hydroxyquinoline (Sigma-Aldrich Company Ltd, Poole, Dorset, UK) to obtain metaphase nuclei. After 2 hours of incubation on ice, root tips were fixed in ethanol: acetic acid (3: 1) at room temperature overnight, then stored in $70 \%$ ethanol at $-20^{\circ} \mathrm{C}$. Fixed root tips were digested in $0.3 \%(\mathrm{w} / \mathrm{v})$ cellulase Onozuka R-10 (Apollo Scientific Ltd, Stockport, Cheshire, UK), 0.3\% (w/v) pectolyase Y23 (MP Biomedicals, Solon, Ohio, USA), and $0.3 \%(\mathrm{w} / \mathrm{v})$ drieselase (SigmaAldrich Company Ltd., Poole, Dorset, UK) for $27 \mathrm{~min}$ and transferred to $1 \%$ citrate buffer $\mathrm{pH} 4.8$ and incubated for 1 hour. The meristematic cells behind the root cap were squashed onto a glass slide in a drop of $60 \%$ acetic acid. Coverslips were removed after freezing in liquid nitrogen.

Fluorescent in situ hybridization (FISH) of the diploids and polyploids followed standard protocols [48]. The probe for $5 \mathrm{~S}$ rDNA was prepared by PCR amplification of the cloned Nicotiana tabacum 5S rRNA gene [49] followed by labeling with biotin-16-dUTP as described in [48]. The probe for $35 \mathrm{~S}$ rDNA was a clone that includes part of the $18 \mathrm{~S}$ rDNA isolated from Allium cernuum, which was labeled with digoxigenin-11-dUTP as described in [48]. Sites of probe hybridization were detected using $20 \mu \mathrm{g} \mathrm{mL}^{-1}$ fluorescein-conjugated antidigoxigenin immunoglobulin (GE Healthcare, Chalfont St Giles, Buckinghamshire, UK) or $5 \mu \mathrm{g} \mathrm{mL} \mathrm{m}^{-1}$ Cy3-conjugated avidin (Roche Pharmaceuticals, Lewes, East Sussex, UK) in $4 \times$ SSC containing $0.2 \%(\mathrm{v} / \mathrm{v})$ Tween 20 and $5 \%(\mathrm{w} / \mathrm{v})$ bovine serum albumin. Chromosomes were counterstained with $2 \mu \mathrm{g} \mathrm{mL} \mathrm{m}^{-1}$ DAPI (4',6-diamidino-2-phenylindole (Sigma-Aldrich Company Ltd. Dorset, UK) in $4 \times$ SSC) and stabilized in Vectashield medium (Vector Laboratories Ltd., Peterborough, UK) prior to data acquisition using a Leica DMRA2 epifluorescent microscope fitted with an Orca ER camera and Open Lab software ${ }^{\odot}$ (Improvision, Coventry, UK). The images were adjusted with Adobe Photoshop ${ }^{\bullet}$ version 7 and treated for color contrast and uniform brightness only. At least five mitotic cells per plant were scored with each probe used.

Table 2 Characteristics of rDNA loci in populations of parental diploid species used for construction of synthetic lines

\begin{tabular}{llllllc}
\hline Species & ${ }^{1}$ Collection no. & Location & ${ }^{2}$ rDNA copies & $\begin{array}{l}\text { rDNA } \\
\text { genotype }\end{array}$ & No. of 35S rDNA sites & No. of 5S rDNA sites \\
\hline T. porrifolius & 2607 & Troy, ID & $1.5 \pm 0.3$ & High-copy & 4 & 4 \\
& 2611 & Pullman, WA & $1.0 \pm 0.2$ & Low-copy & 4 & 4 \\
T. pratensis & 2608 & Moscow, ID & $1.2 \pm 0.1$ & Medium-copy & 2 & 2 \\
& 2609 & Spangle, WA & $1.5 \pm 0.2$ & High-copy & 2 & 2 \\
T. dubius & 2613 & Pullman, WA & $1.7 \pm 0.4$ & High-copy & 2 & 2 \\
& 2615 & Spokane, WA & $0.9 \pm 0.1$ & Low-copy & 2 & 2 \\
\hline
\end{tabular}

'Soltis \& Soltis collection numbers; vouchers deposited at FLAS.

${ }^{2}$ DNA copies per haploid set in thousands. 


\section{DNA isolation, Southern blotting}

Genomic DNA was extracted either from fresh leaves or leaves preserved in RNAlater reagent (Applied Biosystems, Ambion, Warrington, UK), following the instructions of the manufacturer of RNAlater or by a standard CTAB method described in [50] and modified in [51]. DNA concentration was estimated by two independent methods: (i) a CYBR green fluorescence method following a protocol at http://www.dnagenotek.com/); the green fluorescence was measured on a Rotor gene thermocycler (Corbett Research, Brisbane, Australia) as recommended; and (ii) ethidium bromide fluorescence measured after gel electrophoresis using phage lambda DNA as a standard. The estimates obtained from both methods were concordant. Integrity of DNA was checked on gels.

Southern blotting followed the protocol described in [51] using rDNA probes labeled with $\left[\alpha-{ }^{32} \mathrm{P}\right] \mathrm{dCTP}$ (Izotop, Budapest, Hungary). The ITS-1 probe was a Bst NI fragment from the cloned 18S-ITS-5.8S subregion of T. mirus rDNA (GenBank: AY458586). The $18 \mathrm{~S}$ rDNA probe was a cloned $1.7-\mathrm{kb}$ fragment of the tomato $18 \mathrm{~S}$ rRNA gene [52], and the 26S rDNA probe was a 280-bp PCR product derived from the 3 ' end of the tobacco $26 \mathrm{~S}$ rRNA gene [53]. Hybridization signals were visualized by phosphorimaging (Storm, Molecular Dynamics Sunnyvale, CA, USA).

For rDNA quantification, 17.5-200 ng of DNA were denatured in $0.2 \mathrm{M} \mathrm{NaOH}$ and loaded on a nylon membrane (Hybond XL, GE Healthcare, Little Chalfont, UK) using a slot blot apparatus (Schleicher \& Schuell, SigmaAldrich, Dorset, UK). The membranes were hybridized with respective DNA probes in a Church Gilbert buffer [54]. Radioactivity in each band was counted using a rectangle integration method (ImageQuant software, GE Healthcare, Little Chalfont, UK). A standard curve was constructed using a diluted plasmid carrying the $18 \mathrm{~S}$ rDNA insert [52]. The experiments were repeated three times and data averaged.

Statistical calculations were carried out using a chisquare function implemented in MicroSoft Excel.

\section{Results}

\section{Plants and scheme of experiments}

The generation of allotetraploid lines and phenotypic and karyological analysis were described elsewhere [47]. Briefly, the allotetraploids were derived from independent crosses (Figure 1) involving two or three different accessions of diploid T. dubius, T. porrifolius, and $T$. pratensis (Table 2 ). In this study, we used seven lines of synthetic $T$. mirus, four lines of synthetic $T$. miscellus, and two lines of diploid $\mathrm{F}_{1}$ hybrids. The parental origin for each line is given in Table 1. A "line" was defined as the progeny originating from a single cross $\left(S_{0}, S_{1}, S_{2} \ldots\right)$ and maintained through selfing. "Lineages" were obtained by selfing of plants from the same cross but from different $F_{1}$ seeds.

\section{Copy number estimates in diploid genome donors}

Because estimates of rDNA amounts may vary among populations of diploid species, we determined gene copy number of diploid parents using slot blot hybridization. Two to six individuals from each population were analyzed. The DNA was hybridized on blots with the $18 \mathrm{~S}$ rDNA probe and the amount of radioactivity estimated. An example of our hybridization analysis is shown in Additional file 1 . It is evident that the strongest hybridization signals were obtained with DNA from $T$. dubius 2613 and T. porrifolius 2607; these were scored as "high-copy" accessions. On the other hand, T. dubius 2615 and $T$. porrifolius 2611 showed relatively weak hybridization signals and were scored as "low-copy" accessions. Variation within populations and among progeny was low $(<15 \%)$ or negligible. The copy number estimates for each population are given in Table 2 .

\section{Southern blot hybridization in parental plants}

The ITS region was analyzed taking advantage of a diagnostic BstNI restriction site polymorphism that distinguishes the diploid parents. In $T$. dubius, ITS-1 contains a BstNI site close to the $5.8 \mathrm{~S}$ gene while there is no Bst NI site in the ITS-1 of T. porrifolius and T. pratensis [45]. Consistent with previous results, the ITS-1 probe hybridized to the $\sim 700$-bp fragment in T. pratensis and T. porrifolius and to the $\sim 500-\mathrm{bp}$ fragment in $T$. dubius (Figures 2D, 3D).

The IGS region was analyzed using Bst YI and $S s p \mathrm{I}$ restriction enzymes (Additional file 2). There are more BstYI sites in the IGS of T. porrifolius than in T. dubius, based on the sequenced clones [GenBank: FN666261.1 and FN645941.1]. Consequently, the probe hybridized to low-molecular-weight fragments in T. porrifolius and to high-molecular-weight fragments in T. dubius.

\section{FISH analysis in parental plants}

To determine the number and chromosomal position of rRNA genes, we carried out rDNA-FISH on metaphase chromosomes. In T. dubius (Figure 4C), there were two sites of probe hybridization for both $35 \mathrm{~S}$ and $5 \mathrm{~S}$ rDNA, located on the largest chromosome pair $\left(A^{d u}\right.$; the nomenclature follows that of Pires et al. [55]). T. pratensis also has two sites of 35S rDNA (both decondensed) and one pair of $5 \mathrm{~S}$ rDNA loci at metaphase (Figure 4A). Both $35 \mathrm{~S}$ and $5 \mathrm{~S}$ rDNA loci occur on chromosomes $\mathrm{A}^{\mathrm{pr}}$. T. porrifolius has four $35 \mathrm{~S}$ and four $5 \mathrm{~S}$ rDNA sites at metaphase (Figures 4B, D). Chromosome $\mathrm{A}^{\text {po }}$ carries both $35 \mathrm{~S}$ and $5 \mathrm{~S}$ rDNA loci, at homeologous loci to the other diploids, but there are also $35 \mathrm{~S}$ rDNA loci on the 


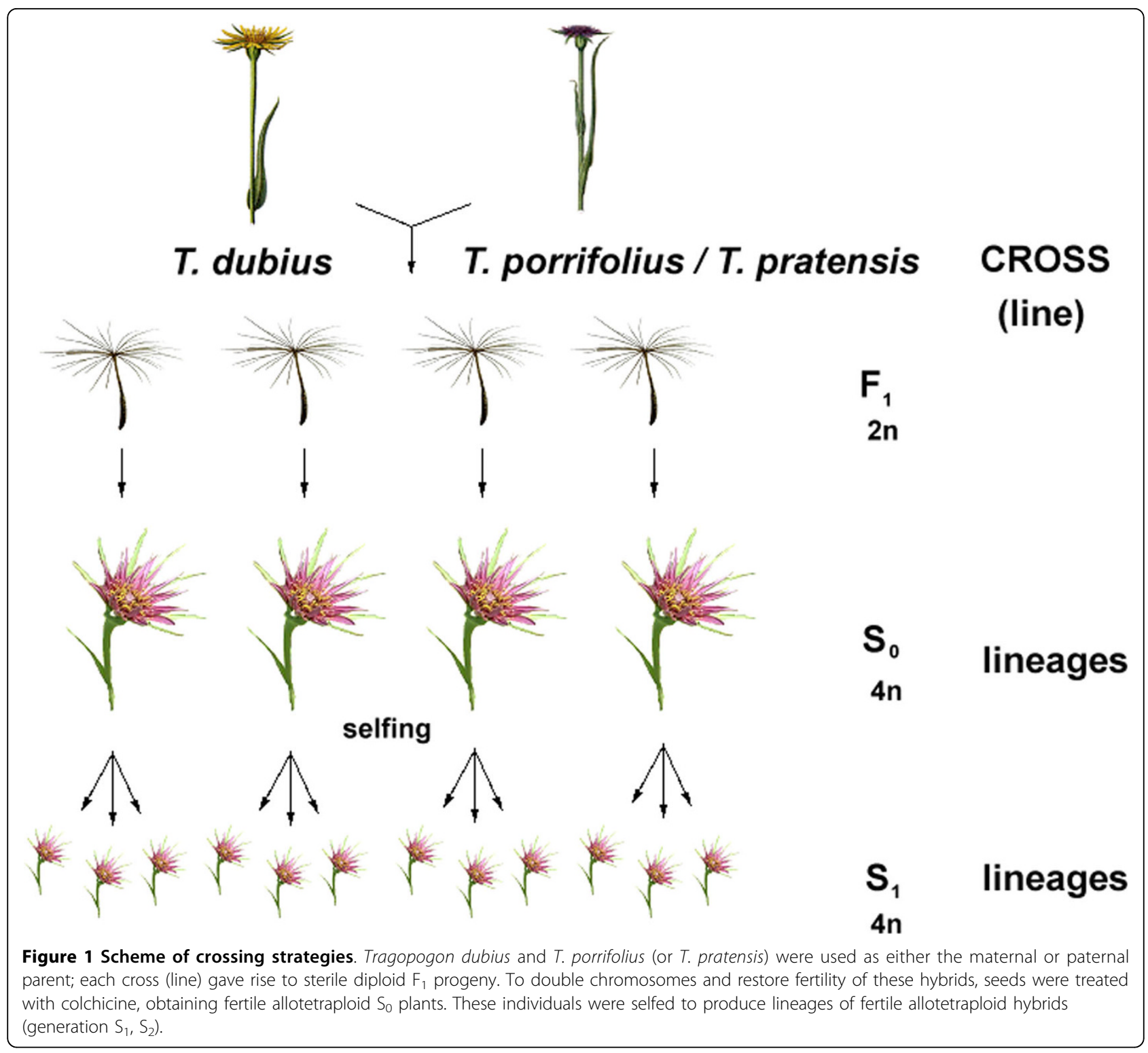

two homologs of chromosome $\mathrm{D}^{\mathrm{po}}$, and 5S rDNA loci on both homologs of chromosome $\mathrm{F}^{\mathrm{po}}$. The $5 \mathrm{~S}$ signal on $\mathrm{A}^{\mathrm{po}}$ was much weaker in accession 2611 (Figure 4D) than in accession 2607 (Figure 4B). The FISH results are consistent with previous cytogenetic analysis carried out in the same diploid populations, but with different individuals [55], indicating chromosomal stability of loci.

\section{Molecular and cytogenetic analysis in synthetic hybrids and allotetraploids}

We carried out a population-level study of 35S rRNA gene copy number using Southern blot hybridization using the ITS-1 probe (Figures 2, 3). The ratios of gene units in each sample are shown in Figures 5A (T. mirus) and $5 \mathrm{~B}$ (T. miscellus); the averaged values for each line are summarized in Figure 5C, D. FISH with the $18 \mathrm{~S}$ rDNA probe was then carried out on selected individuals (Figures 4, 6 and Table 3). In the following sections, we describe the results of both types of analysis for each line derived from diploid parents with high, medium, or low copy numbers at the $35 \mathrm{~S}$ rDNA loci (called high-, medium-, or low-copy) parents.

\section{$F_{1}$ diploid hybrids}

We analyzed rRNA gene ratios using Southern blot hybridization with the ITS-1 probe against diploid $F_{1}$ hybrid plants. In $11 \mathrm{~F}_{1}$ individuals (cross 47 ) from a single cross involving a "high-copy" T. dubius 2613 paternal parent and a "low-copy" T. porrifolius 2611 maternal parent (Figure 2B), the probe hybridized strongly to the 


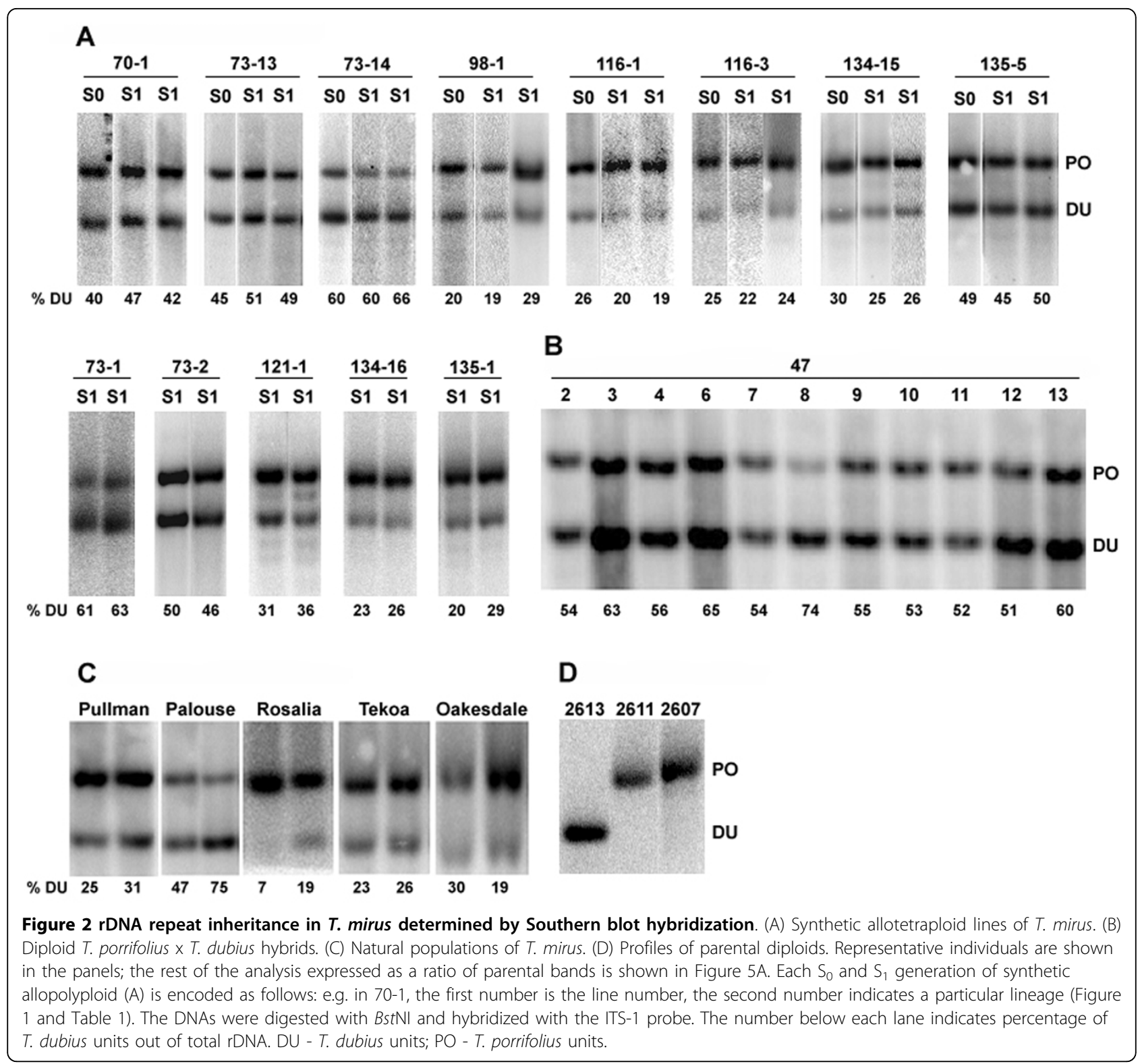

T. dubius-origin rDNA units (DU) forming a lower molecular weight band, while the upper band of $T$. porrifolius-origin rDNA units (PO) was significantly weaker. Radioactivity scanning revealed that on average $60 \%$ of the total hybridization signal occurred in the lower molecular weight band, representing rDNA units of $T$. dubius origin. This value is close to the expected ratio considering the unit copy numbers in the diploid parents (Table 2 and Figure 5C, D). With the exception of one individual (47-8), plant to plant variation in gene ratios was low (Figure 2B). The second diploid hybrid (cross 2) examined was derived from a cross involving "low-copy" T. dubius 2615 and "medium copy" T. pratensis 2607 (Figure 3B). In this case, the upper molecular weight band of $T$. pratensis-origin rDNA units (PR) was stronger than the band inherited from $T$. dubius. Again, $\mathrm{F}_{1}$ hybrids generally showed the expected number of genes inherited from their parents (Figure 5C, D).

\section{Synthetic $T$. mirus}

\section{Line 73}

This line was derived from a cross involving "lowcopy" $2611 \mathrm{~T}$. porrifolius (maternally inherited) and "high-copy" T. dubius 2613 (paternally inherited). Thirty-seven individuals obtained from four lineages (73-1, 73-2, 73-13, and 73-14) were analyzed by Southern blot hybridization using the ITS-1 probe (examples 


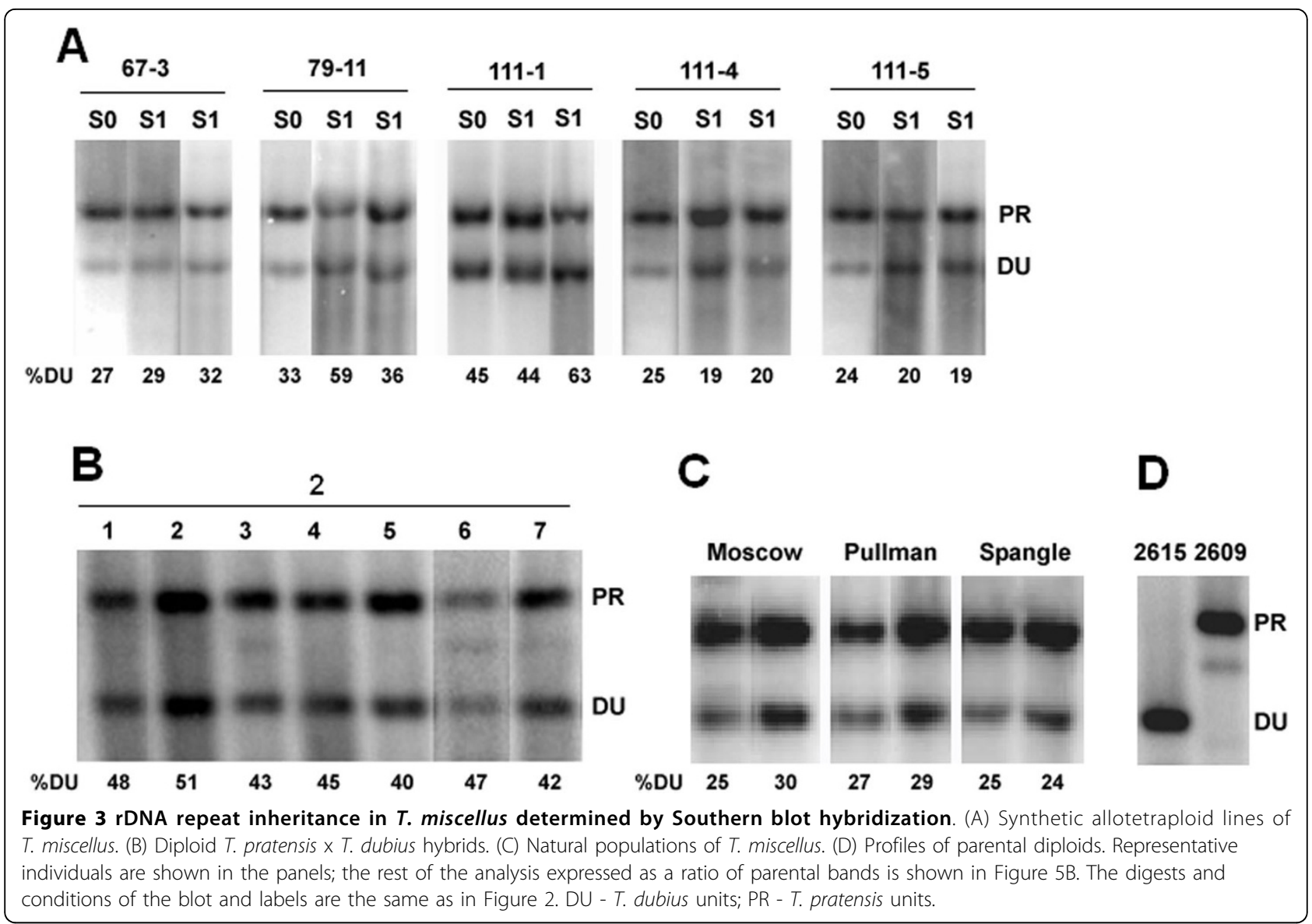

are shown in Figure 2A). There was significant variation in rRNA gene ratios, and at least two distinct rDNA genotypes were distinguished: lineages 73-2 and 73-13 had nearly balanced DU/PO ratios, while lineages 73-1 and 73-14 had ratios skewed towards T. dubius-origin rDNA (61-75\%) (Figures 5A and 5C). The 26S rDNA probe, which mapped polymorphisms in the intergenic spacer (IGS), showed similar results (Additional file 2). The homeolog gene ratios established in the $S_{1}$ seem to be inherited among the $S_{2}$ individuals (Additional file 3).

Representative individuals of both genotypes were analyzed by FISH (Figure 6A, B and 6D). The $18 \mathrm{~S}$ rDNA probe hybridized strongly to terminal regions of both homeologs of chromosomes $\mathrm{A}^{\mathrm{po}}$ and $\mathrm{A}^{\mathrm{du}}$. However, there was no, or very little, hybridization signal on chromosome $\mathrm{D}^{\text {po }}$ (Figure 6B arrowheads), indicating locus loss or drastic elimination of units. This pattern appears to be typical for all $S_{1}$ individuals and their progeny (Additional file 4). There were also quantitative differences in signal intensities. While lineages 73-2 and 7313 had comparable sizes of all four $35 \mathrm{~S}$ rDNA loci, lineages 73-1 and 73-14 had enlarged $A^{\text {du }}$ loci. The number of $5 \mathrm{~S}$ sites was additive (6 signals) in the $S_{1}$ generation while one $S_{2}$ individual gained a strong site likely on chromosome F (Additional file 4D). Thus, cytogenetic and molecular analysis both show considerable variability in rDNA locus sizes in these lineages.

\section{Line 70}

These allopolyploids were derived from "low-copy" T. porrifolius 2611 (maternally inherited) and "highcopy" T. dubius 2613 (paternally inherited), but different individuals were used as parents than in crosses 73 and 98. On the Southern blots, the ratios of parental bands were mostly balanced (Figure 2A). As in line 73, there were only four $35 \mathrm{~S}$ rDNA signals (some with secondary constrictions) instead of the expected six, indicating locus loss (Figure 6C).

\section{Line 98}

Only a single line, 98-1, was recovered from this cross, originating from populations of "low-copy" T. porrifolius 2611 (maternally inherited) and "high-copy" T. dubius 2613 (paternally inherited). Different individuals were used as parents than in the previous two lines. On blots, the probe showed a much stronger hybridization to the band corresponding to the T. porrifolius-origin homeo$\log$ than to the homeolog of $T$. dubius origin (Figure $2 \mathrm{~A})$. There were six $35 \mathrm{~S}$ and six $5 \mathrm{~S}$ rDNA chromosomal 

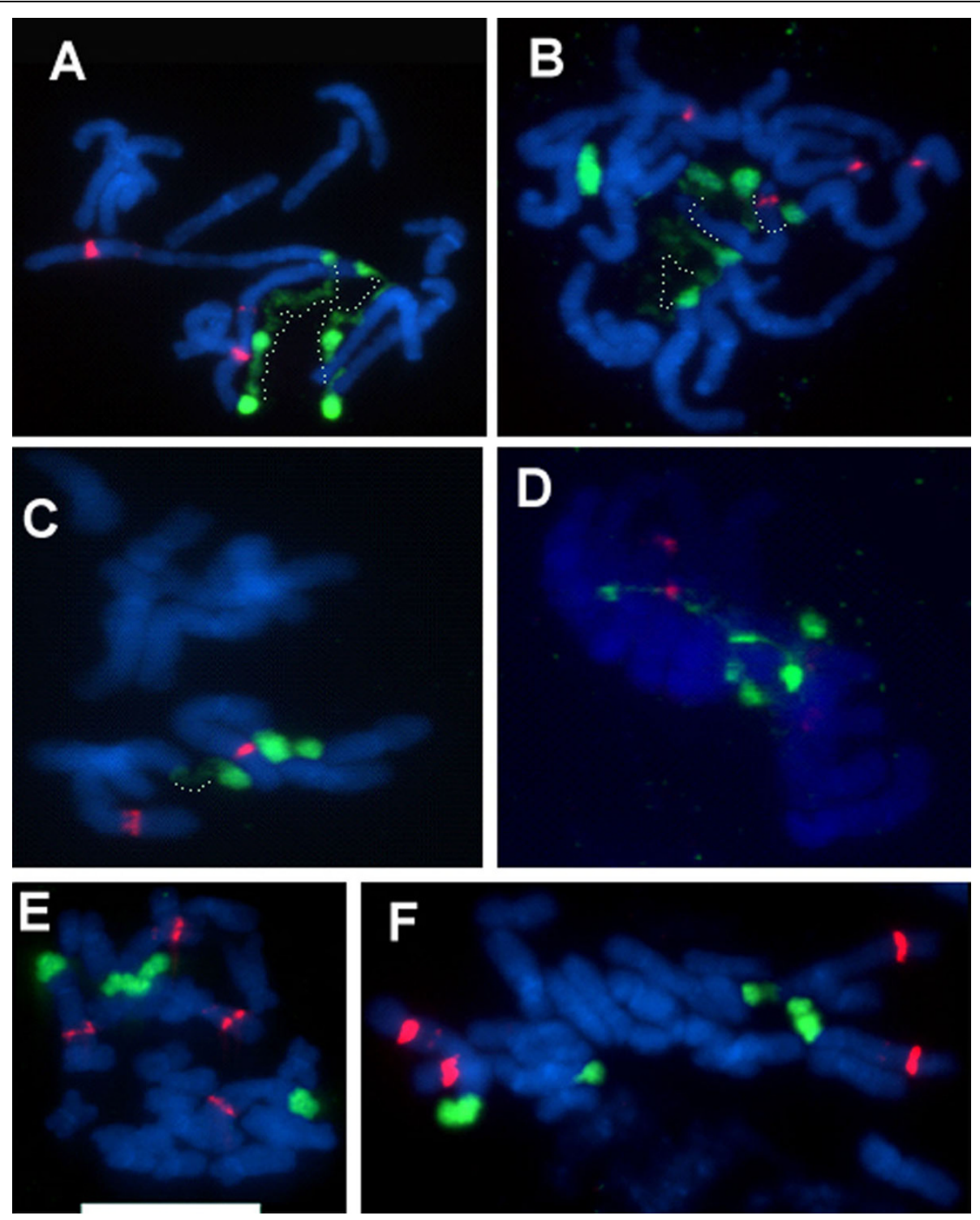

Figure 4 FISH to metaphase spreads of parental diploid species (A-D) and synthetic T. miscellus lines (E-F). (A) T. pratensis 2608. (B) T. porrifolius 2607. (C) T. dubius 2613. (D) T. porrifolius 2611. (E) and (F) stand for the 111-1 and 111-4 synthetic individuals, respectively. Metaphases were hybridized with the 185 rDNA (painting 355 sites in green) and $5 \mathrm{~S}$ rDNA (red fluorescence) probes. Note the discontinuous chromatin condensation along the loci. Regions of condensed and decondensed chromatin are interconnected with dotted lines in (A-C). Scale bar $=10 \mu \mathrm{m}$.

sites, indicating an additive number of loci from that expected of the diploid parents (Figure 6E).

\section{Line 116}

In this cross we used "high-copy" T. porrifolius 2607 as the maternal genome donor and "low-copy" T. dubius 2615 as the paternal genome donor. All individuals from eight lineages showed relatively uniform Southern hybridization profiles, with band ratios highly skewed towards the T. porrifolius-origin units (Figures 2A, 5). FISH showed the expected number of $35 \mathrm{~S}$ signals, with signals on chromosomes $\mathrm{A}^{\mathrm{po}}, \mathrm{D}^{\mathrm{po}}$, and $\mathrm{A}^{\mathrm{du}}$, although the signals on chromosome $\mathrm{A}^{\mathrm{du}}$ (arrows) are smaller and highly decondensed (Figure 6G). On the other hand, the
35S signals on T. porrifolius chromosomes were strong, and NORs on $\mathrm{D}^{\text {po }}$ (arrowheads) showed only partial decondensation.

Line 121

This line originated from a cross involving "low-copy" T. dubius 2615 as the maternal parent and a "highcopy" T. porrifolius 2607 as a donor of the paternal genome. The gene ratio of all eight allotetraploid individuals was slightly shifted towards the T. porrifolius homeolog (Figure 5A). FISH was not conducted on this line.

\section{Line 134}

This line was derived from a "high-copy" T. porrifolius 2607 (maternally inherited) and a "high-copy" T. dubius 


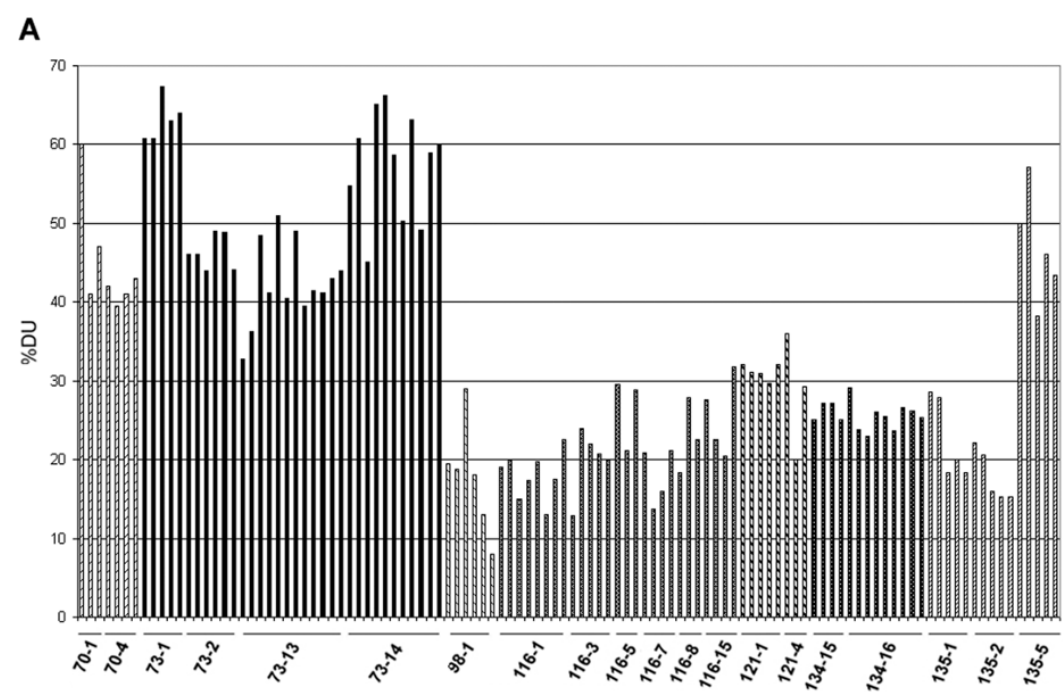

B
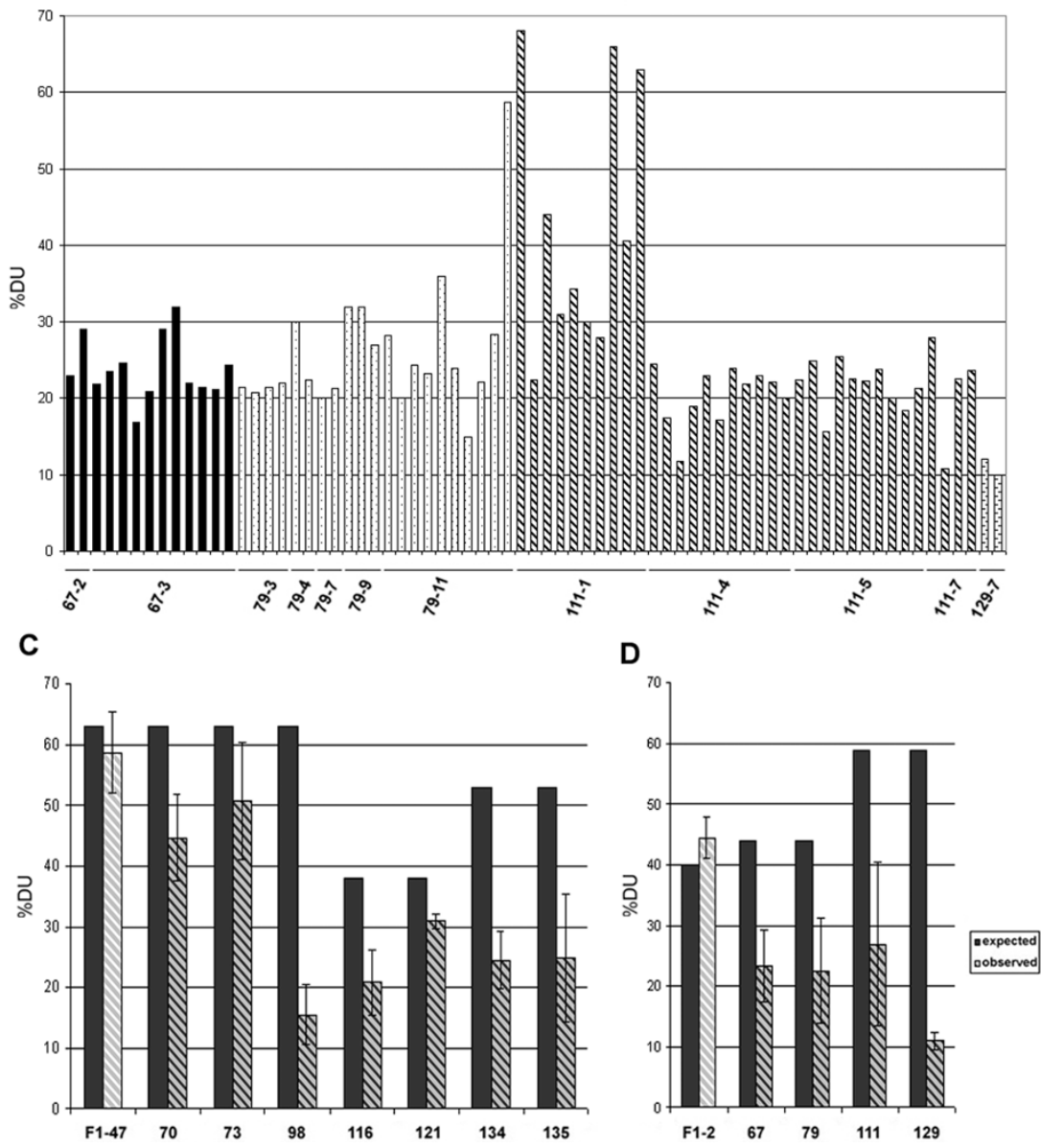

Figure 5 Summary of rDNA repeat ratios analysis estimated for individual synthetic T. mirus (A, C) and T. miscellus (B, D) plants Homeolog gene ratios were determined from quantification of band signals after the Southern blot hybridization (Figures 2, 3). Each parental hybridization band was quantified using phosphorimaging, and gene ratios were expressed as a percentage of $T$. dubius units out of the total signal (A, B). The averaged values for each line are shown in graphs ( $C$ and $D$ - shaded bars); for $F_{1}$ diploid hybrids the shaded bars are drawn at low contrast. Filled bars represent expected gene ratios based on strict Mendelian inheritance of gene copy numbers. The interindividual variability within the line is expressed by standard deviation from the mean. Differences between expected and observed ratios were highly significant $\left(P<0.001\right.$, standard chi-square test) in all lines except the diploid $F_{1}-47$ and $F_{1}-2$ hybrids and line 121. 

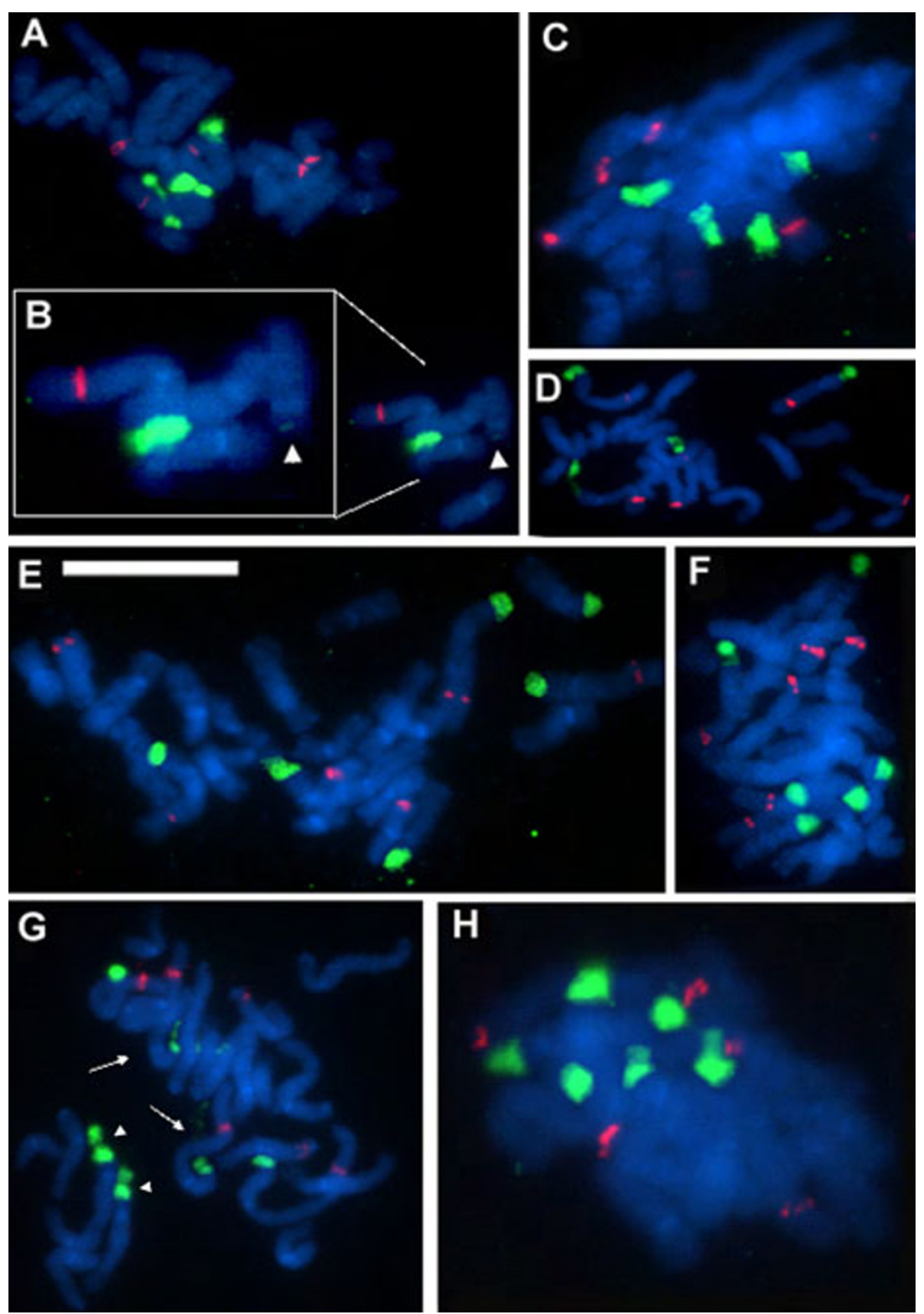

Figure 6 FISH to metaphase spreads of synthetic T. mirus. The probe labels and scale bar are as in Figure 4. Individuals 73-14 (A, B), 70-4 (C), and 73-13 (D) had four strong plus 0-2 very weak signals (dependent on particular metaphase and sample). (B) is an expanded region of (A) showing the large locus of $T$. dubius origin and the minute $D^{\text {po }}$ locus (arrowheads) left after the deletion of the majority of genes from the array. Lineages 98-1 (E), 134-15 (F), 116-1 (G), and 135-5 (H) showed regularly six 18S rDNA signals. The metaphase in $(G)$ has largely decondensed $A^{\text {du }}$ (arrows), partially decondensed $\mathrm{D}^{\mathrm{po}}$ (arrowheads), and fully condensed $\mathrm{A}^{\mathrm{po}}$ loci.

2613 (paternally inherited) and yielded two lineages (134-15 and 134-16). On the blots, individuals from both lines showed a relatively weak $T$. dubius-origin band and a strong $T$. porrifolius-origin band (Figures $2 \mathrm{~A}, 5)$. At the cytogenetic level, the individuals inherited an additive number of $35 \mathrm{~S}$ rDNA loci, four strong sites and two weaker ones, the latter likely of $T$. dubius origin, that are slightly remote from the bulk of the chromosomes due to secondary constriction (Figure 6F).

\section{Line 135}

This line originated from a cross reciprocal to that giving line 134 and comprised three lineages (1, 2, and 5). 
Table 3 Summary of cytogenetic analysis

\begin{tabular}{|c|c|c|c|}
\hline Species & ${ }^{3} N$ & $35 S$ rDNA sites & $5 S$ rDNA sites \\
\hline Synthetic T. mirus ${ }^{1}$ & 17 & $4-6$ & $6-7$ \\
\hline Natural T. mirus ${ }^{2}$ & 11 & $6^{4}$ & $6-7$ \\
\hline Synthetic T. miscellus ${ }^{1}$ & 2 & 4 & 4 \\
\hline Natural T. miscellus ${ }^{2}$ & 6 & 4 & 4 \\
\hline
\end{tabular}

${ }^{1}$ this study.

2 references $[45,46,55]$.

${ }^{3}$ number of individuals analyzed by rDNA-FISH.

${ }^{4}$ some individuals from population Rosalia [45] had a nearly deleted locus on chromosome $\mathrm{A}^{\mathrm{du}}$ inherited from $T$. dubius (Figure $2 \mathrm{C}$ ).

While both lineages $135-1$ and $135-2$ had gene ratios skewed towards $T$. porrifolius-origin units, the gene ratios were balanced in the 135-5 individuals (Figures $2 \mathrm{~A}, 5)$. There was some variability among the 135-5 individuals (Figure 5A). However, the number of loci was additive in the individual examined using FISH (Figure $6 \mathrm{H})$.

\section{Synthetic $T$. miscellus}

\section{Line 67}

In this cross, a "high-copy" T. pratensis 2609 was used as the maternal genome donor and "low-copy" T. dubius 2616 as the paternal genome donor. There was little or no variation in the gene ratios among the individuals analyzed, and all individuals had reduced Southern hybridization signal against the $T$. dubius-origin units (Figure 3A).

\section{Line 79}

This cross is a reciprocal cross to that which generated line 67, and it yielded 5 lineages. There was some, albeit little, intralineage variability in band hybridization signal intensities. For example, the $S_{1}$ individual in the middle lane (Figure 3A) had a stronger T. dubius-origin band compared to that from the other parent ( $T$. pratensis) while most other members of this line had a dominant band of T. pratensis origin (Figure 5B).

\section{Line 111}

In this cross a "medium-copy" T. pratensis 2608 (maternally inherited) and "high-copy" T. dubius 2613 (paternally inherited) were used as genome donors. This combination of parents yielded the largest number of allotetraploid individuals (35) out of the T. miscellus crosses attempted. Lineages 111-4, 111-5, and 111-7 had relatively uniform profiles of Southern hybridization bands with ratios skewed away from the units of T. dubius origin (Figure 3A). Lineage 111-1 differed in having relatively large intralineage variability (Figure 5B). There were individuals with signals skewed towards the T. pratensis type as well as individuals with balanced gene ratios. FISH was carried out on randomly selected individuals of lineages 111-1 (Figure 4E) and (Figure 4F). Both plants retained an additive number of $35 \mathrm{~S}$ and $5 \mathrm{~S}$
rDNA loci from that expected of the diploid parents (i.e., four $35 \mathrm{~S}$ and four $5 \mathrm{~S}$ rDNA sites). However, plant 111-4 had two larger and two smaller $35 \mathrm{~S}$ rDNA signals, all with secondary constrictions, while individual 111-1 had signals of comparable sizes on all four chromosomes.

\section{Line 129}

Line 129 resulted from a cross reciprocal to that which generated line 111. Only two allotetraploid individuals were recovered from this cross, and both had gene ratios highly skewed away from $T$. dubius-origin units (Figure 5B).

\section{Discussion}

rRNA gene copy number variation in synthetic $T$. mirus and $T$. miscellus

We analyzed the inheritance of rRNA genes in seven lines of synthetic T. mirus and four lines of synthetic $T$. miscellus. In synthetic T. mirus, 32 individuals (29\%) exhibited balanced rDNA genotypes, 69 individuals (63\%) showed more $35 \mathrm{~S}$ rDNA of T. porrifolius origin than expected, and only 9 plants $(8 \%)$ had more $T$. dubius-origin rDNA (Table 4). In synthetic T. miscellus, three individuals $(4 \%)$ had balanced gene ratios while 65 individuals (92\%) inherited more T. pratensis-origin units than expected. The genetic variation in copy ratios among the progeny of a single cross ranged from low or

\begin{tabular}{|c|c|c|c|c|}
\hline Species & Genotype & $\begin{array}{l}\text { Gene ratio, Du: } \\
\text { Po/Pr }\end{array}$ & ${ }^{7} N$ & $\begin{array}{c}\% \text { of } \\
\text { individuals }\end{array}$ \\
\hline \multirow[t]{4}{*}{ Synthetic T. mirus } & high Du & $>60 \%$ & 9 & 8 \\
\hline & balanced & $40-60 \%$ & 32 & 29 \\
\hline & high Po & $>60 \%$ & 69 & 63 \\
\hline & total & & 110 & \\
\hline \multirow[t]{4}{*}{ Natural T. mirus } & high Du & $>60 \%$ & 0 & 0 \\
\hline & balanced & $40-60 \%$ & 20 & 29 \\
\hline & high Po & $>60 \%$ & 48 & 71 \\
\hline & total & & 68 & \\
\hline \multirow{4}{*}{$\begin{array}{l}\text { Synthetic } T \text {. } \\
\text { miscellus }\end{array}$} & high Du & $>60 \%$ & 3 & 4 \\
\hline & balanced & $40-60 \%$ & 3 & 4 \\
\hline & high Pr & $>60 \%$ & 65 & 92 \\
\hline & total & & 71 & \\
\hline \multirow{4}{*}{$\begin{array}{l}\text { Natural } T \text {. } \\
\text { miscellus }\end{array}$} & high Du & $>60 \%$ & 0 & 0 \\
\hline & balanced & $40-60 \%$ & 0 & 0 \\
\hline & high $\mathrm{Pr}$ & $>60 \%$ & 31 & 100 \\
\hline & total & & 31 & \\
\hline
\end{tabular}

${ }^{1} \mathrm{~N}$ - number of individuals. The data were obtained from the $\mathrm{S}_{1}$ generation of synthetic lines (Table 1); natural populations were analyzed in $[45,60]$. 
negligible (5\%, line 134) to high (40\%, line 111) (Figure $5 \mathrm{C})$. Some crosses involving the same parental accessions (lines 70, 73, and 98) gave rise to individuals with expected ratios of parental $35 \mathrm{~S}$ rDNA units considering the copy numbers in the diploid parents, while others had rDNA genotypes balanced or skewed towards units derived from either of the diploid parents.

\section{Sources of rDNA copy number variability in allotetraploids}

(i) Contribution of natural variation in parental accessions

There may be up to two-fold variation in 35S rDNA copy number between different accessions of the same Tragopogon species. The differences in copy number were larger between populations of the same species than between species. These data indicate that shifts in rDNA array sizes occur at the lineage level. Similar levels of interpopulation variability were reported among Arabidopsis accessions [56]. As a consequence, hybridizing species may inherit a variable number of rRNA genes depending on the parental populations involved. This hypothesis has been tested in $\mathrm{F}_{1}$ diploid hybrids. For example, a "low-copy" T. dubius accession 2615 combined with a "high-copy" T. porrifolius 2607 should generate skewed 1:2 DU/PO ratios in a hybrid (lines 116 and 121, Figure 5C). Conversely, a "high-copy" T. dubius 2613 combined with a "low-copy" T. porrifolius 2611 should result in a 2:1 DU/PO gene ratio. Indeed, the analysis of $F_{1}$ diploid hybrids confirmed the unequal gene dosage inherited from both parents (Figures 2, 3, and 5). However, many allopolyploid lines involving a "high-copy" T. dubius parent showed far fewer copies of this parental type than expected, suggesting that standing variation in diploids does not account for all observed rDNA imbalances in the derived polyploids.

Another source of "inherited variation" may stem from heterozygosity in locus sizes in the parents. For example, in Streptocarpus a major rDNA locus occurs in a hemizygous condition, accounting for gene copy number variation in derived hybrids [57]. This sort of heterozygosity would be evident if there were a very low-copy array and a very high-copy array in parents. However, FISH analysis revealed no indication of rDNA heterozygosity in the diploid Tragopogon individuals investigated, a situation which might be expected for species that are largely selfing [58,59], and in plants that were derived from inbred lines propagated in a greenhouse (at least one generation). In estimating rDNA locus sizes, and hence relative copy numbers at individual loci, FISH may be influenced by the condensation state of the chromatin. However, we examined many cells in making our assessments and did not observe heterozygozity even in the most condensed metaphases. Furthermore, our data revealed clear associations between the size of the FISH signal and the number of rRNA gene copies estimated by Southern hybridization. Most $\mathrm{F}_{1}$ diploid hybrids showed gene copy number ratios that were close to expectation. However, one $F_{1}$ individual (47-8) resulting from the cross $T$. dubius $2613 \times T$. porrifolius 2611 showed altered homeolog gene ratios from Mendelian expectation (Figure 2B). Further, segregation of IGS sequence polymorphisms upon selfing of parental diploids was noted in some cases (Hana Malinska unpublished). Whether these low-frequency events reflect heterozygosity in locus sizes, gametic variation or postzygotic changes is currently unknown.

In short, the genetic variation among the parents contributed some, but certainly not a major portion of the rDNA variability seen in the allotetraploids.

\section{(ii) Contribution of allopolyploidy-related factors to rDNA variability}

We observed deviations from expected gene ratios in most of the synthetic tetraploid individuals we examined (Figures 5C, D). The Southern blot and FISH data further show that this was mainly caused by underrepresentation of T. dubius-origin units. Directionality of the change is not influenced by the partner genome being either T. pratensis or T. porrifolius in origin, as similar patterns occurred in both synthetic T. mirus and T. miscellus. However, the extent and frequency of these changes differed among the lines of the same species. For example, the expected 2:1 DU/PO ratio of units has been reversed into a 1:4 ratio in line 98 of synthetic T. mirus, whereas in other lines the ratios changed relatively little (line 121). In general, deviation from repeat additivity occurred more frequently in lines resulting from crosses involving T. dubius 2613 as a parent than any other accession (Figure 5). The contribution of parental cytoplasm to gene imbalances could be assessed from the analysis of reciprocally formed individuals. The average DU/PO gene ratios in reciprocally formed lines (134 and 135) of T. mirus were comparable (Figure 5C) although variation was higher in line 135 that inherited T. dubius 2613 as a mother genome donor. However, relatively few individuals (28) were sampled to allow firm conclusion on this topic. Variation within lines was generally lower than that between the lines. Nevertheless, members of lineage 111-1 (synthetic T. miscellus) did show much variation (Figure 5B), and most segregating progeny differed from the parental genotype.

Repeat number variation was reflected by differences in $35 \mathrm{~S}$ rDNA locus sizes. For example, line 116 of synthetic T. mirus, which has only $19 \% \mathrm{rDNA}$ of $T$. dubius origin, showed small FISH signals on both $A^{\text {du }}$ homologs in contrast to signals on $\mathrm{A}^{\mathrm{po}}$ and $\mathrm{D}^{\mathrm{po}}$; their small sizes are indicative of loss in rDNA repeats at this locus (Figure 6G). However, the high level of decondensation 
occurring at one or both $\mathrm{A}^{\mathrm{du}}$ sites suggests a high level of transcriptional activity at the preceding interphase. Indeed, RT-PCR experiments confirmed strong expression dominance of $T$. dubius loci in this (Additional file 5) and other lines of synthetic T. mirus and T. miscellus (Hana Malinska - unpublished). High transcriptional activity from an rDNA locus with reduced rRNA gene copy numbers has also been reported previously for natural T. mirus and T. miscellus individuals [60]. Similarly, FISH revealed that lineage 111-4 of T. miscellus had two small and two large rDNA loci (Figure $4 \mathrm{~F}$ ) while a sister lineage, 111-1, had four large sites at both rDNA loci on chromosomes $\mathrm{A}^{\mathrm{pr}}$ and $\mathrm{A}^{\mathrm{du}}$ (Figure 4E). Line 111-1 also had more $T$. dubius-origin gene copies than individual 111-4 (Figure 3A). Thus, FISH analysis confirmed that the shifts in rRNA gene ratios were likely caused by contractions of repeats on the $\mathrm{A}^{\mathrm{du}}$ locus. Synthetic $T$. mirus lineage 73-14 is a notable exception in having an extremely large $\mathrm{A}^{\mathrm{du}}$ locus (Figures $6 \mathrm{~A}, \mathrm{~B}$ and Additional files $4 \mathrm{~A}, \mathrm{~B}, \mathrm{C})$. This may have been caused by amplification of repeats within the locus, but the plants also have a smaller locus on the other $\mathrm{A}^{\mathrm{du}}$ homolog, potentially indicating translocation of repeats between homologs, perhaps as a consequence of unequal recombination at meiosis.

\section{Mechanisms of rDNA rearrangements}

Meiotic aberrations have been implicated in rRNA gene imbalances in natural populations of Tragopogon (e.g., [46]). Indeed, meiotic analysis of eight $S_{1}$ plants (same material as used in this study) revealed a number of abnormalities, including multivalent formation, lagging chromosomes, and aneuploidy [47]. Chromosomes bearing rDNA appeared to be frequently involved in the formation of bridge complexes. Interestingly, lines involving T. dubius 2613 (70 and 98) showed higher frequencies of both meiotic irregularities and rDNA rearrangements than lines derived from other accessions. There seems to be a good correlation between meiotic pairing abnormalities and frequency of rDNA changes in Tragopogon. Ribosomal RNA gene copy number losses may occur through unequal recombination (perhaps also recombination between non-homologous or homologous chromosomes).

Shifts in gene ratios were also observed in some $S_{0}$ plants (i.e., the premeiotic synthetic allotetraploids), arguing that meiotic irregularities may not be the only mechanism responsible for rDNA rearrangements, but mechanisms acting during or immediately after genome doubling could also be involved. Such mechanisms include recombination between rDNA loci (at homologous loci or otherwise), aneuploidy, and chromosome loss in somatic cells, the latter two having been reported in interspecific Arabidopsis hybrids and allopolyploids
[61]. Reciprocal aneuploidy (loss compensated by gain of another chromosome of the complement) might explain the occurrence of four major 35S rDNA sites instead of six in T. mirus synthetic lines 70 and 73 (Figure 6). However, most synthetic polyploid individuals had the expected number of rDNA loci, and significantly altered gene ratios are likely arising through rearrangements targeted at the locus itself. In yeast, recombination between sister chromatids of the same chromosomes were shown to be a major source of array contractions and expansions [62,63]. A similar mitotic driven mechanism seems to be responsible for changes in copy number during development of Vicia faba [17] and in flax genotrophs [64]. Occasionally prolonged treatment with mitotic inhibitors causes the sister chromatids to separate but not to segregate as the cell proceeds towards anaphase. In one synthetic T. mirus cell (Additional file 4E) we observed that the chromatids were held together only at the rDNA loci, perhaps indicating unresolved recombination sites with $\mathrm{rDNA}$, as can occur at the anaphase checkpoint in yeast $[65,66]$. Mitotic problems may underlie the high mortality of $\mathrm{S}_{0}$ generation plants in which $>50 \%$ of individuals did not survive or were sterile [47].

We have recently proposed that the nucleolus could be a site of inter- and intralocus recombination [67]. This hypothesis is supported by observation of increased homologous pairing at NORs in interphase of Arabidopsis [68]. Perhaps the decondensed chromatin of highly active genes promotes genetic recombination during interphase, resulting in the contraction/ expansion of arrays. Another possibility is that subrepeated regions of the IGS may stimulate recombinogenic activity of units [17]. The IGS subrepeats in the sequenced T. dubius unit are longer and more homogeneous than those present in the $T$. porrifolius unit (Additional file 6). T. dubius arrays displayed greater level of variation than the $T$. porrifolius arrays in the allopolyploid lines.

\section{Comparison of natural and synthetic populations of allotetraploids}

T. mirus and T. miscellus in the wild formed repeatedly within the last century and hence represent a unique system for studying the early stages of genome evolution following interspecific hybridization and genome duplication. In some areas, the progenitor diploids still occur along with expanding populations of the allotetraploids, and the polyploids at those locations likely represent descendents of the nearby diploid populations [69]. This scenario would apply, for example, to the T. mirus collections from Pullman, Washington. The collected $T$. dubius individuals from Pullman (2613) have nearly two-fold higher rDNA copy number compared to $T$. 
porrifolius (2611) at the same location. Yet, in both natural populations of $T$. mirus allotetraploids sampled, the T. dubius rDNA represents only $20-25 \%$ of the total rDNA [45] perhaps suggesting that $\sim 75 \%$ of $A^{\text {du }}$ repeats have been lost in the approximately 30-40 generations since the polyploids (which are biennials) formed at these locations. We were surprised to discover that one (98) out of three lines of T. mirus synthesized from Pullman parents showed a genotype that closely resembled that of both natural populations. The gene imbalances were, however, less pronounced in the other two lines $(70,73)$. In line 73 some individuals even had more $T$. dubius units, indicating that array size could be both maintained and altered during allopolyploidy. Interestingly, one natural population of T. mirus (from Palouse, Washington) also contained individuals with ratios skewed away from $T$. porrifolius (Figure 2 and Table 4). These examples illustrate that, as in other allopolyploid species [24,25], concerted evolution may occur bidirectionally in Tragopogon despite the prevalent trend towards contraction of $T$. dubius arrays in most plants and populations. In contrast to other systems $[24,28,40,70,71]$, we have no molecular evidence for interlocus recombination of rDNA in either natural or synthetic populations of Tragopogon although sequence analysis of ITS clones has not been conducted in synthetic material.

Natural populations of allotetraploids of independent origin differ morphologically, biochemically, and genetically [39] although these allotetraploids apparently originated from a relatively narrow genetic pool of parental populations [69]. One explanation for interpopulational diversity in the allopolyploids is that genetic variation was triggered during the early generations post-allopolyploidization. This hypothesis is supported by an observation that the same parental accessions may give rise to lineages with differing rDNA genotypes. Brassica napus allotetraploids appear to share many features with the Tragopogon system, including homeolog pairing [72,73] and preliminary data that indicate that some rDNA loci may be lost in early generations (Ales Kovarik - unpublished). In contrast to rDNAs, low-copy, protein-coding sequences do not seem to be markedly altered in the early generations of the synthetic lines of $T$. mirus and T. miscellus [74]. Perhaps rearrangements of low-copy genes lag behind changes in the highly repeated fraction of the genome.

It is assumed that, as time passes, homogenization processes such as unequal crossing over continue to gradually replace parental rDNA arrays with novel allopolyploid species arrays. However, the time factor does not seem to be the only player. For example, while most Old World Tragopogon allotetraploids (assumed to be of ancient origin) homogenized ITS nearly to completion another old allotetraploid, Tragopogon castellanus, retained equivalent amounts of both parental ITS types [75]. Similarly, in rice [26] and Glycine [25] most, but not all, populations homogenized parental rDNAs. We envisage that the extent and tempo of rDNA homogenization in older allopolyploids is largely influenced by genetic and epigenetic changes in the early generations of allopolyploids. The fact that some rDNA genotypes seen in 80-year-old allopolyploids are already evident in the first generation of synthetic lines supports this hypothesis. However, this does not exclude the possibility that other changes in rDNA loci can occur gradually and stochastically over extended periods of time.

\section{Conclusions}

We observed similar reductions of homeologous rRNA gene copies in both synthetic and natural, 80-year-old populations of Tragopogon allopolyploids, indicating that some aspects of genome evolution might be repeatable. The biological significance of gene losses as well as their potential adaptive significance is unclear. Uniparental deletions (partial or complete) would not affect fitness because there is a large excess of genes in the partner genome. One possibility is that intralocus rearrangements (translocation, deletions, amplification) preclude interlocus homogenization in older allopolyploids. The latter process is frequently associated with reduction of loci and repeats [67]. It is therefore possible that gene elimination/shrinkage of arrays serves as an alternative regulatory mechanism to epigenetic silencing, reducing the number of functional genes in a cell. Recently, Hawkins et al. [76] proposed that DNA loss may counterbalance genome expansion through retrotransposon proliferation. Perhaps rRNA gene elimination may reflect general tandem repeat instability in the allopolyploid nucleus. Retroelement activity in Tragopogon populations remains to be analyzed. Finally, rDNA arrays were recently shown to influence gene expression at ectopic positions in Drosophila [77], and locus size could potentially serve as an epigenetic regulator harmonizing the expression of subgenomes.

\section{Additional material}

Additional file 1: Slot blot quantification of gene copies in parental diploids. The DNA amounts are indicated above each lane. The blot was hybridized with the ${ }^{32} \mathrm{P}$ - labeled 185 rDNA probe. Experiments I and II were carried out in this study; experiment III is from [45].

Additional file 2: Analysis of intergenic rDNA spacer polymorphisms in DNA of synthetic $\boldsymbol{T}$. mirus $\left(\mathrm{S}_{\mathbf{1}}\right.$ generation). Genomic DNA was digested with BstYl and Sspl restriction enzymes. Southern blot hybridization was carried out using the $26 \mathrm{~S}$ rDNA probe. 
Additional file 3: Southern blot analysis of the $S_{2}$ generation of synthetic $\boldsymbol{T}$. mirus. Individuals were the progenies of three lineages from line 73 .

Additional file 4: FISH analysis of the $S_{2}$ generation of synthetic $T$. mirus. The same plants as in Additional file 3 were analyzed. Most metaphases displayed aneuploid karyotypes (23 chromosomes). Arrowheads in (C, F) indicate a minute $D^{\text {po }}$ locus left after the deletion of the majority of genes. Note fusion of subtelomeric NORs at the chromatids (arrowheads, E) and considerable variability in condensation of rDNA chromatin among sister plants $(A-C)$. The following individuals are shown: (A) - 73-14-6A, (B) - 73-14-6B, (C) - 73-14-6C, (D, E) - 73-1-3 D, (F) - 73-2-8B

Additional file 5: Expression analysis of rDNA in synthetic $T$. mirus (line 116). RNA isolation and RT-CAPS assay were carried out as described in [60]. Note typical inverse correlation between gene copy number (grey bars) and their expression (black bars).

\section{Additional file 6: Analysis of IGS subrepeats in T. dubius 2613 and} T. porrifolius 2611. We used a dot plot alignment tool at http://www. vivo.colostate.edu/molkit/dnadot/, self ( $x$-axis) to self ( $y$-axis) alignment (Window size: 9 . Mismatch limit: 0). The IGSs were amplified using primers designed to conserved regions in 265 rDNA and 185 rDNA [10]. Briefly, the $\sim 3.5-\mathrm{kb}$ PCR products obtained were cloned into PSC-B-amp/ kan vector using StrataClone Blunt PCR Cloning Kit (Stratagene, La Jolla, CA, USA). Clones bearing inserts of expected lengths were initially sequenced from both ends using universal M13 reverse and T7 primers. To obtain full-length sequence, the IGS-specific primers were designed based on the partial sequence. Five new primers were needed to cover the whole IGS region.

\section{List of abbreviations}

ITS: internal transcribed spacer; IGS: intergenic spacer; FISH: fluorescent in situ hybridization; NOR: nucleolar organizer region; Organisms: T. dubius: Tragopogon dubius; T. mirus: Tragopogon mirus; T. miscellus: Tragopogon miscellus; T. porrifolius: Tragopogon porrifolius; T. pratensis: Tragopogon pratensis

\section{Acknowledgements}

We thank Dr Blazena Koukalova (Institute of Biophysics, ASCR) for helpful discussions and critical reading of the manuscript. Drs Simon Renny-Byfield and Michael Chester (University of London) are acknowledged for advice and expertise with the FISH method. This research was funded by the Grant Agency of the Czech Republic P501-10-0208, 206/09/1751, the Academy of Sciences of the Czech Republic (AVOZ50040507 and AVOZ50040702) and EMBO fellowship to HM (224-2009). Additional support for this research was provided by NSF grants MCB-0346437 to DES, PSS, and JAT; DEB-0614421 to DES and PSS, and DEB-0919254/0919348 to DES, PSS, W. B. Barbazuk, and P. S. Schnable.

\section{Author details}

${ }^{1}$ Institute of Biophysics, Academy of Sciences of the Czech Republic, v.v.i, Laboratory of Molecular Epigenetics, Kralovopolska 135, CZ-61265 Brno, Czech Republic. ${ }^{2}$ Institute of Molecular BioSciences, Massey University, Palmerston North 4442, New Zealand. ${ }^{3}$ School of Biological Sciences, Queen Mary University of London, E1 4NS, UK. ${ }^{4}$ Department of Biology, University of Florida, Gainesville, FL 32611, USA. ${ }^{5}$ Florida Museum of Natural History, University of Florida, Gainesville, FL 32611, USA.

\section{Authors' contributions}

HM carried out most of the molecular biology and cytogenetic experiments. AK, DS, PS, and AL designed the study. AK wrote and drafted the paper. RM participated in the DNA analysis. AL carried out some FISH experiments. JT made the crosses and prepared synthetic lines. All authors read and approved the final manuscript.

Received: 16 June 2010 Accepted: 22 September 2010 Published: 22 September 2010

\section{References}

1. Soltis PS, Soltis DE: The role of hybridization in plant speciation. Ann Rev Plant Biol 2009, 60:561-588.

2. Wood TE, Takebayashi N, Barker MS, Mayrose I, Greenspoon PB, Rieseberg LH: The frequency of polyploid speciation in vascular plants. Proc Natl Acad Sci USA 2009, 106(33):13875-13879.

3. Cui L, Wall PK, Leebens-Mack JH, Lindsay BG, Soltis DE, Doyle JJ, Soltis PS, Carlson JE, Arumuganathan K, Barakat A, et al: Widespread genome duplications throughout the history of flowering plants. Genome Res 2006, 16(6):738-749.

4. Soltis DE, Albert VA, Leebens-Mack J, Bell CD, Paterson AH, Zheng CF, Sankoff D, dePamphilis CW, Wall PK, Soltis PS: Polyploidy and angiosperm diversification. Am J Bot 2009, 96(1):336-348.

5. Leitch AR, Leitch IJ: Genomic plasticity and the diversity of polyploid plants. Science 2008, 320(5875):481-483.

6. Jones RN, Hegarty M: Order out of chaos in the hybrid plant nucleus. Cytogenet Genome Res 2009, 126(4):376-389.

7. Doyle JJ, Flagel LE, Paterson AH, Rapp RA, Soltis DE, Soltis PS, Wendel JF: Evolutionary genetics of genome merger and doubling in plants. Ann Rev Genet 2008, 42:443-461.

8. Hemleben V, Zentgraf U: Structural organisation and regulation of transcription by RNA polymerase I of plant nuclear ribosomal genes. In Results and problems in cell differentiation 20: Plant promoters and transcription factors. Edited by: Berlin LN. Heidelberg: Springer-Verlag; 1994:3-24

9. Neves N, Delgado M, Silva M, Caperta A, Morais-Cecilio L, Viegas W: Ribosomal DNA heterochromatin in plants. Cytogenet Genome Res 2005, 109(1-3):104-111.

10. Garcia S, Lim KY, Chester M, Garnatje T, Pellicer J, Valles J, Leitch AR, Kovarik A: Linkage of 35S and 5S rRNA genes in Artemisia (family Asteraceae): first evidence from angiosperms. Chromosoma 2009, 118(1):85-97.

11. Alvarez I, Wendel JW: Ribosomal ITS sequences and plant phylogenetic inference. Mol Phylogenet Evol 2003, 29:417-434.

12. Komarova NY, Grimm GW, Hemleben V, Volkov RA: Molecular evolution of $35 \mathrm{~S}$ rDNA and taxonomic status of Lycopersicon within Solanum sect. Petota. Plant Syst Evol 2008, 276(1-2):59-71.

13. Skalicka K, Lim KY, Matyasek R, Koukalova B, Leitch A, Kovarik A: Rapid evolution of parental rDNA in a synthetic tobacco allotetraploid line. Am J Bot 2003, 90(7):988-996.

14. Bennett RI, Smith AG: Use of a genomic clone for ribosomal RNA from Brassica oleracea in RFLP analysis of Brassica species. Plant Mol Biol 1991, 16(4):685-688.

15. Ingle J, Timmins JN, Sinclair J: The relationship between satellite deoxyribonucleic acid, ribosomal ribonucleic acid gene redundancy, and genome size in plants. Plant Physiol 1975, 55:496-501.

16. Dubcovsky J, Dvorak J: Ribosomal RNA multigene loci - Nomads of the Triticeae genomes. Genetics 1995, 140(4):1367-1377.

17. Rogers SO, Bendich AJ: Heritability and variability in ribosomal RNA genes of Vicia faba. Genetics 1987, 117:285-295.

18. Dover GA: Molecular drive: a cohesive mode of species evolution. Nature 1982, 299:111-117.

19. Zimmer EA, Martin SL, Beverley SM, Kan YW, Wilson AC: Rapid duplication and loss of genes coding for the alpha chains of hemoglobin. Proc Nat Acad Sci USA 1980, 77(4):2158-2162.

20. Nieto Feliner G, Rossello JA: Better the devil you know? Guidelines for insightful utilization of nrDNA ITS in species-level evolutionary studies in plants. Mol Phylogenet Evol 2007, 44(2):911-919.

21. Kotseruba V, Pistrick K, Blattner FR, Kumke K, Weiss O, Rutten T, Fuchs J, Endo T, Nasuda S, Ghukasyan A, et al: The evolution of the hexaploid grass Zingeria kochii (Mez) Tzvel. $(2 n=12)$ was accompanied by complex hybridization and uniparental loss of ribosomal DNA. Mol Phylogenet Evol 2010, 56(1):146-155

22. Lim KY, Matyasek R, Kovarik A, Leitch A: Parental origin and genome evolution in the allopolyploid Iris versicolor. Ann Bot-London 2007, 100(2):219-224.

23. Winterfeld G, Schneier J, Roser M: Allopolyploid origin of mediterranean species in Helictotrichon (Poaceae) and its consequences for karyotype repatterning and homogenisation of rDNA repeat units. Syst Biodivers 2009, 7(3):277-295. 
24. Wendel JF, Schnabel A, Seelanan T: Bidirectional interlocus concerted evolution following allopolyploid speciation in cotton (Gossypium). Proc Natl Acad Sci USA 1995, 92(1):280-284

25. Joly S, Rauscher JT, Sherman-Broyles SL, Brown AH, Doyle JJ: Evolutionary dynamics and preferential expression of homeologous 18S-5.8S-26S nuclear ribosomal genes in natural and artificial glycine allopolyploids. Mol Biol Evol 2004, 21(7):1409-1421.

26. Bao Y, Wendel JF, Ge S: Multiple patterns of rDNA evolution following polyploidy in Oryza. Mol Phylogenet Evol 2010, 55(1):136-142.

27. Fuertes Aguilar J, Rossello JA, Nieto Feliner G: Nuclear ribosomal DNA (nrDNA) concerted evolution in natural and artificial hybrids of Armeria (Plumbaginaceae). Mol Ecol 1999, 8(8):1341-1346.

28. Kovarik A, Matyasek R, Lim KY, Skalicka K, Koukalova B, Knapp S, Chase M, Leitch A: Concerted evolution of 18-5.8-26S rDNA repeats in Nicotiana allotetraploids. Biol J Linn Soc London 2004, 82:615-625.

29. Volkov RA, Borisjuk NV, Schweizer D, Hemleben V: Elimination and rearrangement of parental rDNA in the allotetraploid Nicotiana tabacum. Mol Biol Evol 1999, 16(3):311-320.

30. Kovarik A, Werlemark G, Leitch AR, Souckova-Skalicka K, Lim YK, Khaitova L, Koukalova B, Nybom $\mathrm{H}$ : The asymmetric meiosis in pentaploid dogroses (Rosa sect. Caninae) is associated with a skewed distribution of rRNA gene families in the gametes. Heredity 2008, 101(4):359-367.

31. Sang T, Crawford DJ, Stuessy TF: Documentation of reticulate evolution in peonies (Paeonia) using internal transcribed spacer sequences of nuclear ribosomal DNA: implications for biogeography and concerted evolution. Proc Natl Acad Sci USA 1995, 92(15):6813-6817.

32. Fehrer J, Krak K, Chrtek J Jr: Intra-individual polymorphism in diploid and apomictic polyploid hawkweeds (Hieracium, Lactuceae, Asteraceae): disentangling phylogenetic signal, reticulation, and noise. BMC Evol Biol 2009, 9:239.

33. O'Kane SL, Schaal BA, Al-Shehbaz IA: The origins of Arabidopsis suecica as indicated by nuclear rDNA sequences. Syst Bot 1996, 21:559-566.

34. Pontes O, Neves N, Silva M, Lewis MS, Madlung A, Comai L, Viegas W, Pikaard CS: Chromosomal locus rearrangements are a rapid response to formation of the allotetraploid Arabidopsis suecica genome. Proc Natl Acad Sci USA 2004, 101(52):18240-18245.

35. Shcherban AB, Badaeva ED, Amosova AV, Adonina IG, Salina EA: Genetic and epigenetic changes of rDNA in a synthetic allotetraploid, Aegilops sharonensis x Ae. umbellulata. Genome 2008, 51(4):261-271.

36. Urbanska KM, Hurka H, Landolt E, Neuffer E, Mummenhoff K: Hybridization and evolution in Cardamine (Brassicaceae) at Urnerboden, Central Schwitzerland: biosystematics and molecular evidence. Plant Syst Evol 1997, 204:233-256.

37. Ainouche ML, Baumel A, Salmon A: Spartina anglica Schreb.: a natural model system for analysing evolutionary changes that affect allopolyploid genomes. Biol J Linn Soc London 2004, 82:475-484.

38. Abbott RJ, Lowe AJ: Origins, establishment and evolution of two new polyploid species of Senecio in the British Isles. Biol J Linn Soc London 2004, 82:467-474.

39. Soltis DE, Soltis PS, Pires JC, Kovarik A, Tate J: Recent and recurrent polyploidy in Tragopogon (Asteraceae): Genetics, genomic, and cytogenetic comparisons. Biol J Linn Soc London 2004, 82:485-501.

40. Franzke A, Mummenhoff K: Recent hybrid speciation in Cardamine (Brassicacea)-conversion of nuclear ribosomal ITS sequences in statu nascendi. Theor Appl Genet 1999, 98:831-834.

41. Ainouche ML, Fortune PM, Salmon A, Parisod C, Grandbastien MA, Fukunaga K, Ricou M, Misset MT: Hybridization, polyploidy and invasion: lessons from Spartina (Poaceae). Biol Invasions 2009, 11(5):1159-1173.

42. Ownbey M: Natural hybridization and amphiploidy in the genus Tragopogon. Am J Bot 1950, 37:487-499.

43. Tate JA, Ni Z, Scheen AC, Koh J, Gilbert CA, Lefkowitz D, Chen ZJ, Soltis PS, Soltis DE: Evolution and expression of homeologous loci in Tragopogon miscellus (Asteraceae), a recent and reciprocally formed allopolyploid. Genetics 2006, 173(3):1599-1611.

44. Buggs RJA, Doust AN, Tate JA, Koh J, Soltis K, Feltus FA, Paterson AH, Soltis PS, Soltis DE: Gene loss and silencing in Tragopogon miscellus (Asteraceae): comparison of natural and synthetic allotetraploids. Heredity 2009, 103(1):73-81.

45. Kovarik A, Pires JC, Leitch AR, Lim KY, Sherwood AM, Matyasek R, Rocca J, Soltis DE, Soltis PS: Rapid concerted evolution of nuclear ribosomal DNA in two Tragopogon allopolyploids of recent and recurrent origin. Genetics 2005, 169(2):931-944

46. Lim KY, Soltis DE, Soltis PS, Tate J, Matyasek R, Srubarova H, Kovarik A, Pires JC, Xiong Z, Leitch AR: Rapid chromosome evolution in recently formed polyploids in Tragopogon (Asteraceae). PLoS One 2008, 3(10): e3353.

47. Tate JA, Symonds W, Doust AN, Buggs RJA, Mavrodiev E, Majure LC, Soltis PS, Soltis DE: Synthetic polyploids of Tragopogon miscellus and $T$. mirus (Asteraceae): 60 Years after Ownbey's discovery. Am J Bot 2009, 96(5):979-988.

48. Leitch AR, Lim KY, Webb DR, McFadden Gl: In situ hybridisation. In Plant Cell Biology, a practical approach. Edited by: Hawes CS-JB. Oxford: Oxford University Press; 2001:267-293.

49. Fulnecek J, Matyasek R, Kovarik A, Bezdek M: Mapping of 5-methylcytosine residues in Nicotiana tabacum $5 S$ rRNA genes by genomic sequencing. Mol Gen Genet 1998, 259(2):133-141.

50. Doyle JJ, Doyle JL: A rapid DNA isolation procedure for small quantities of fresh leaf tissue. Phytochem Bull 1987, 19:11-15.

51. Kovarik A, Koukalova B, Lim KY, Matyasek R, Lichtenstein CP, Leitch AR, Bezdek M: Comparative analysis of DNA methylation in tobacco heterochromatic sequences. Chromosome Res 2000, 8(6):527-541.

52. Kiss T, Szkukalek A, Solymosy F: Nucleotide sequence of a $17 \mathrm{~S}$ (18S) rRNA gene from tomato. Nucleic Acids Res 1989, 17(5):2127.

53. Lim KY, Matyasek R, Lichtenstein CP, Leitch AR: Molecular cytogenetic analyses and phylogenetic studies in the Nicotiana section Tomentosae. Chromosoma 2000, 109(4):245-258.

54. Sambrook J, Fritsch EF, Maniatis T: Molecular cloning: A laboratory manual. New York: Cold Spring Harbor Laboratory Press 1988.

55. Pires JC, Lim KY, Kovarik A, Matyasek R, Boyd A, Leitch AR, Leitch IJ, Bennett MD, Soltis PS, Soltis DE: Molecular cytogenetic analysis of recently evolved Tragopogon (Asteraceae) allopolyploids reveal a karyotype that is additive of the diploid progenitors. Am J Bot 2004 91(7):1022-1035

56. Woo HR, Richards EJ: Natural variation in DNA methylation in ribosomal RNA genes of Arabidopsis thaliana. BMC Plant Biol 2008, 8:92.

57. Denduangboripant J, Cronk QCB, Kokubugata G, Moller M: Variation and inheritance of nuclear ribosomal DNA clusters in Streptocarpus (Gesneriaceae) and their biological and phylogenetic implications. Int J Plant Sci 2007, 168(4):455-467.

58. Cook LM, Soltis PS: Mating systems of diploid and allotetraploid populations of Tragopogon (Asteraceae). II. Artificial populations. Heredity 2000, 84:410-415.

59. Cook LM, Soltis PS: Mating systems of diploid and allotetraploid populations of Tragopogon (Asteraceae). I. Natural populations. Heredity 1999, 82:237-244.

60. Matyasek R, Tate JA, Lim YK, Srubarova H, Koh J, Leitch AR, Soltis DE, Soltis PS, Kovarik A: Concerted evolution of rDNA in recently formed Tragopogon allotetraploids is typically associated with an inverse correlation between gene copy number and expression. Genetics 2007, 176(4):2509-2519.

61. Wright KM, Pires JC, Madlung A: Mitotic instability in resynthesized and natural polyploids of the genus Arabidopsis (Brassicaceae). Am J Bot 2009, 96(9):1656-1664.

62. Petes TD: Unequal meiotic recombination within tandem arrays of yeast ribosomal DNA genes. Cell 1980, 19(3):765-774.

63. Kobayashi T, Ganley ARD: Recombination regulation by transcriptioninduced cohesin dissociation in rDNA repeats. Science 2005 309(5740):1581-1584.

64. Cullis CA: Quantitative variation of ribosomal RNA genes in flax genotrophs. Heredity 1979, 42:237-246.

65. Win TZ, Mankouri HW, Hickson ID, Wang SW: A role for the fission yeast Rqh1 helicase in chromosome segregation. J Cell Sci 2005, 118(24):5777-5784.

66. Torres-Rosell J, Machin F, Farmer S, Jarmuz A, Eydmann T, Dalgaard JZ, Aragon L: SMC5 and SMC6 genes are required for the segregation of repetitive chromosome regions. Nat Cell Biol 2005, 7(4):412-448.

67. Kovarik A, Dadejova M, Lim YK, Chase MW, Clarkson JJ, Knapp S, Leitch AR Evolution of rDNA in Nicotiana allopolyploids: A potential link between rDNA homogenization and epigenetics. Ann Bot-London 2008, 101(6):815-823. 
68. Pecinka A, Schubert V, Meister A, Kreth G, Klatte M, Lysak MA, Fuchs J, Schubert I: Chromosome territory arrangement and homologous pairing in nuclei of Arabidopsis thaliana are predominantly random except for NOR-bearing chromosomes. Chromosoma 2004, 113(5):258-269.

69. Symonds W, Soltis PS, Soltis DE: Dynamics of polyploid formation in Tragopogon (Asteraceae): Recurrent formation, gene flow, and population structure. Evolution 2010, 64(7):1984-2003.

70. Aguilar JF, Rossello JA, Feliner GN: Nuclear ribosomal DNA (nrDNA) concerted evolution in natural and artificial hybrids of Armeria (Plumbaginaceae). Mol Ecol 1999, 8(8):1341-1346.

71. Mummenhoff K: Recent hybrid speciation in Cardamine (Brassicacea)conversion of nuclear ribosomal ITS sequences in statu nascendi. Theor Appl Genet 1999, 98:831-834.

72. Gaeta RT, Chris Pires J: Homoeologous recombination in allopolyploids: the polyploid ratchet. New Phytol 2010, 186(1):18-28.

73. Szadkowski E, Eber F, Huteau V, Lode M, Huneau C, Belcram H, Coriton O Manzanares-Dauleux MJ, Delourme R, King GJ, et al: The first meiosis of resynthesized Brassica napus, a genome blender. New Phytol 2010, 186(1):102-112.

74. Tate JA, Joshi P, Soltis KA, Soltis PS, Soltis DE: On the road to diploidization? Homoeolog loss in independently formed populations of the allopolyploid Tragopogon miscellus (Asteraceae). BMC Plant Biol 2009, 9:80.

75. Mavrodiev EV, Soltis PS, Soltis DE: Putative parentage of six Old World polyploids in Tragopogon L. (Asteraceae: Scorzonerinae) based on ITS, ETS, and plastid sequence data. Taxon 2008, 57(4):1215-1232.

76. Hawkins JS, Grover CE, Wendel JF: Repeated big bangs and the expanding universe: Directionality in plant genome size evolution. Plant Sci 2008, 174(6):557-562.

77. Paredes S, Maggert KA: Ribosomal DNA contributes to global chromatin regulation. Proc Natl Acad Sci USA 2009, 106(42):17829-17834.

doi:10.1186/1471-2148-10-291

Cite this article as: Malinska et al: Similar patterns of rDNA evolution in synthetic and recently formed natural populations of Tragopogon (Asteraceae) allotetraploids. BMC Evolutionary Biology 2010 10:291.

\section{Submit your next manuscript to BioMed Central and take full advantage of:}

- Convenient online submission

- Thorough peer review

- No space constraints or color figure charges

- Immediate publication on acceptance

- Inclusion in PubMed, CAS, Scopus and Google Scholar

- Research which is freely available for redistribution

Submit your manuscript at www.biomedcentral.com/submit
Biomed Central 